\title{
STUDI TENTANG PENTINGNYA KOMUNIKASI DALAM PEMBINAAN KELUARGA
}

\author{
Oleh: Awaluddin ${ }^{1}$ \\ ${ }^{1}$ Institut Agama Islam Muhammadiyah Sinjai, \\ J1. Sultan Hasanuddin, No. 20 Balangnipa, Sinjai \\ E-mail: awaluddin.iaimsinjaigmail.com, Tlp: +6285242053496
}

\begin{abstract}
Abstrak
Jurnal ini berjudul "Studi tentang Pentingnya Komunikasi dalam Pembinaan Keluarga", merupakan kajian dalam bentuk penelitian kepustakaan (Library Research). Skripsi ini dibahas dengan menggunakan pendekatan paedagogik dan dibahas dengan analisis isi.

Keluarga adalah institusi pertama dan merupakan lembaga yang paling bertanggung jawab terhadap peletakan dasar-dasar pendidikan anak. Di dalam keluarga, terdapat orang tua yang terdiri dari bapak dan ibu, memiliki tanggung jawab yang sangat besar terhadap pendidikan anak-anaknya. Pengembangan sikap, watak dan kepribadian anak sangat ditentukan oleh bagaimana bentuk pembinaan dan pendidikan yang diterima dari kedua orang tuanya.

Dalam rangka mendidik anak di dalam lingkungan rumah tangga, para orang tua dituntut untuk memiliki kemampuan dalam mengarahkan dan membimbing anak-anaknya. Apa yang disampaikan oleh orang tua kepada anak memerlukan strategi yang tepat sehingga pesan-pesan yang disampaikannya dapat diterima oleh anak dengan sebaik-baiknya sehingga keharmonisan antara orang tua dengan anak tetap terjaga. Selain itu, komunikasi yang baik antara orang tua dengan anak akan senantiasa memberikan jaminan emosional bagi anak-anak sehingga anakanak dapat mengalami perkembangan kejiwaan secara wajar.

Agar strategi komunikasi yang diterapkan dapat berjalan dengan baik, maka orang tua perlu untuk meningkatkan pengetahuan dan kemampuannya baik dengan melalui bacaan-bacaan maupun dengan melalui diskusi antara suami dengan isteri sehingga dapat dipilih cara yang tepat dan melakukan komunikasi.
\end{abstract}

\section{Kata Kunci: Komunikasi, Keluarga}

\section{PENDAHULUAN}

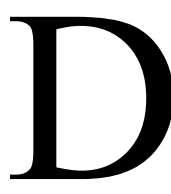
alam dunia pendidikan para ahli keluarga adalah lingkungan pertama dan utama dalam kehidupan anak. Dalam lingkungan keluarga seorang anak mendapatkan pendidikan awal sebagai basis pertama pendidikan bagi pertumbuhan dan perkembangan fungsi-fungsi jiwanya. Keluarga adalah institusi pendidikan yang pertama-tama dikenal oleh seorang anak. Oleh karena itu, lingkungan keluarga bisa juga disebut sebagai sekolah pertama yang dikenal oleh anak. Begitu pentingnya lingkungan keluarga bagi awal kehidupan seorang anak maka orang tua sebagai penanggung jawab memegang peranan penting dalam mengikuti setiap tahap pertumbuhan dan perkembangan anak.

Keluarga adalah lembaga pendidikan informal yang tidak hanya bertanggung jawab terhadap pendidikan dalam arti yang sempit, tetapi pendidikan dalam keluarga mempunyai peranan yang sangat besar dalam semua aspek kehidupan anak. Dengan demikian, keluarga mempunyai fungsifungsi yang begitu luas. 
Lingkungan keluarga yang menjadi tempat mengadu segala kebutuhan, serta pengaruh tekanan kejiwaan dalam diri anak. Tekanan-tekanan itu kadang-kadang muncul sebagai akibat dari interaksi terhadap lingkungan pergaulannya. Walau bagaimana pun anak adalah sosok manusia juga yang tent unya mempunyai kebutuhan dan keinginan sendiri. Namun, keinginan anak kadang berbenturan dengan norma-norma yang ada baik itu norma agama maupun norma adat kesusilaan.

Diakui bahwa seorang anak sebelum memasuki dunia pendidikan sekolah ia telah memiliki pengalaman tentang kehidupan sekitarnya, khususnya selama masa-masa bersama dengan orang tuanya di dalam lingkungan keluarga.

Secara psikologis, pertumbuhan dan perkembangan jiwa anak, juga dapat dipengaruhi oleh apa yang dilihat, didengar, dan dirasakan dari semua sistem pendidikan yang diterapkan di dalam keluarga semestinya dimantapkan sehingga pertumbuhan dan perkembangan anak dapat berlangsung dengan mantap pula.

Salah satu aspek terpenting dalam proses berlangsungnya pendidikan di dalam keluarga adalah aspek komunikasi antara orang tua dengan anak. Salah menerapkan atau keliru dalam melakukan komunikasi dengan anak dapat membawa dampak yang kurang baik bagi pertumbuhan dan perkembangan jiwanya kelak. Karena itu, komunikasi merupakan hal yang perlu dibangun antara orang tua dengan anak di dalam keluarga, sebelum anak memasuki dunia yang lebih luas dalam bentuk interaksi sosial kemasyarakatan. Sebagai awal bagi anak untuk memasuki dunia dewasa yang penuh liku dan tantangan.

\section{PEMBAHASAN}

\section{A. Pengertian Komunikasi}

Dalam kegiatan hidup manusia, komunikasi adalah hal yang selalu terjadi. Komunikasi itu dilakukan sebagai bentuk kegiatan yang memperlancar roda kehidupan. Tanpa komunikasi, manusia tidak akan dapat berhubungan antara satu dengan yang lainnya. Oleh karena itu, komunikasi adalah sarana yang mutlak diperlukan.

Sebelum membahas lebih lanjut tentang komunikasi dalam kehidupan, maka terlebih dahulu harus dipahami tentang pengertian komunikasi dengan jelas dan tepat sehingga di dalam memahami tulisan ini, akan dapat searah dengan maksud isinya.

Istilah komunikasi dalam bahasa Inggeris communication berasal dari kata Latin, yaitu communicasio yang jika ditelusuri asal katanya berasal dari kata Communis yang berarti sama atau sama makna (Onong Uchjana Effendi, 1990: 9).

Dalam bahasa Inggeris, komunikasi berasal dari kata communication yang berarti perbuatan atau pernyataan berkomunikasi, berhubungan lewat kata-kata, tulisan-tulisan atau gambar-gambar (Osman Raliby, 1984: 107).

Oleh karena itu, komunikasi antara manusia merupakan sesuatu aspek yang sangat menentukan dinamika kehidupan manusia, maka sudah barang tentu dalam proses komunikasi tersebut terdapat 
berbagai macam bentuk komunikasi antara manusia. Onong Uchjana Effendi merinci bentuk komunikasi sebagai berikut:

a. Komunikasi personal

b. Komunikasi kelompok

c. Komunikasi massa

d. Komunikasi media (Onong Uchjana Effendi, 1990: 7).

Melihat pendapat tersebut di atas, maka dapatlah penulis simpulkan bahwa secara umum komunikasi dapat dikelompokkan ke dalam dua bentuk, yaitu:

\section{Komunikasi Langsung}

Komunikasi langsung adalah komunikasi yang dilakukan, yaitu antara penyampai pesan dengan penerima pesan dapat saling bertatapan muka secara langsung. Dalam komunikasi jenis ini, komunikator dapat menilai dan melihat hasil-hasil dari pesan-pesan komunikasi yang dilakukan.

Dalam pembagian ini, dikenal komunikasi intrapersonal dan komunikasi antarpersonal. Komunikasi intrapersonal adalah komunikasi yang terjadi secara monologis, yaitu komunikator tidak dapat mengetahui keadaan komunikan apakah pesan-pesan yang disampaikan diterima atau tidak.

Untuk mengubah sikap sebagai suatu tujuan komunikasi, maka komunikasi antarpersonal sangat efektif dilakukan karena komunikasi jenis ini sifatnya dialogis dan terjadi secara timbal balik. Komunikator dapat mengetahui situasi dan keadaan komunikan, apakah komunikan menganggapnya secara positif atau negatif.

Dalam komunikasi antarpersonal ini yang dihadapi hanya seorang saja sehingga dapat terjadi umpan balik antara komunikator dan komunikan. Arus balik yang terjadi dapat diketahui secara langsung.

Ada lagi bentuk komunikasi langsung dalam bentuk lain, yaitu komunikasi kelompok. Dalam komunikasi jenis ini, jumlah massa yang dihadapi lebih dari satu atau dua orang. Dalam komunikasi jenis ini, komunikator juga berhadapan langsung dengan komunikan sehingga arus valik pun dapat terjadi. Sejumlah komunikan dapat diketahui bagaimana mereka menanggapi komunikator yang sedang melakukan penyampaian pesan-pesan.

Dalam kaitan ini, komunikasi kelompok dapat dibedakan atau komunikasi kelompok besar dan komunikasi kelompok kecil. Terdapat perbedaan antara komunikasi kelompok kecil dengan komunikasi kelompok besar. Komunikasi kelompok kecil, misalnya kuliah, seminar, dan sebagainya. Dalam hal ini, umpan balik yang diperlukan oleh komunikator adalah yang bersifat verbal karena komunikasinya ditujukan kepada pengetahuan komunikan.

Dengan demikian, maka umpan balik sangat memainkan peranan yang besar dalam sistem komunikasi langsung, sebab ia menentukan kelanjutan dari komunikasi yang sedang dilaku-kan oleh komunikator. 
Oleh karena itu, umpan balik dapat bersifat positif atau negatif. Terjadinya umpan balik yang positif, jika komunikator mampu menyampaikan pesan-pesan komunikasi yang dapat menyenangkan bagi komunikan. Sedangkan sebaliknya komunikasi yang berlangsung dengan membosankan dan menjemukan komunikan akan membuat komunikan memberikan respon yang negatif.

\section{Komunikasi Tidak Langsung}

Komunikasi tidak langsung adalah komunikasi yang terjadi dimana pesan-pesan yang disampaikan berlangsung dengan menggunakan perantara. Dalam komunikasi model ini, komunikator dan komunikan tidak saling bertatapan langsung atau dengan kata lain komunikator menyampaikan pesan-pesannya dengan menggunakan alat.

Dilihat dari segi efisiensi, maka komunikasi secara tidak langsung lebih efisien karena dapat menjangkau tempat-tempat yang jauh sekalipun.

Dalam komunikasi tidak langsung komunikator dapat menyampaikan pesan-pesannya secara lebih luas dan sebebas-bebasnya karena komunikan hanya melihat atau mendengar atau membaca apa yang disampaikan oleh komunikator. Namun, antara keduanya dapat saja terjadi umpan balik, yang biasa disebut dengan umpan balik tertunda. Karena terjadinya umpan balik tersebut, memerlukan waktu yang berselang sehingga umpan balik memerlukan waktu untuk sampai kepada komuni-kan atau sebaliknya.

Memahami kedua pengertian di atas, dapat diperoleh pengertian bahwa komunikasi adalah sarana yang dibentuk oleh manusia sebaga alat penghubung dalam kegiatan hidupnya sebagai sarana memperlancar urusan-urusan hidup manusia.

Dengan berkembangnya ilmu pengetahuan dan teknologi serta semakin tingginya peradaban manusia, maka teknologi komunikasi juga semakin meningkat. Karena komunikasi tidak lagi terbatas, maksudnya pada hal-hal seperti menerima, mengerti, dan mengetahui pesan-pesan komunikasi. Tetapi komunikasi sudah merupakan sarana dalam mengadakan perubahan sesuai dengan pesan-pesan komunikasi.

James G. Robins dan Barbara S. Jones dalam bukunya yang berjudul Effective Today's Manager, mengemukakan sebagai berikut;

Komunikasi adalah suatu tingkah laku, perbuatan atau kegiatan penyampaian dan pengoperan lambang-lambang yang mengandung arti atau makna atau perbuatan penyampaian suatu gagasan atau komunikasi dari seseorang kepada orang lain. Atau lebih jelasnya adalah suatu pemindahan atau penyampaian informasi mengenai pikiran dan perasaan-perasaan (James, Robins dan Barbara S. Jone, diterjemahkan oleh R. Thurman Sirait, 1986: 1).

Komunikasi menunjukkan adanya suatu efektivitas pada seseorang yaitu efektivitas penyampaian informasi atau pesan-pesan apa saja sehingga terjadi interaksi antara seseorang dengan orang lain. Terjadinya interaksi tersebut akan menimbulkan respon timbal balik antara penyampai pesan dengan penerima pesan. Suharsimi Arikunto dalam bukunya yang berjudul Organisasi dan Administrasi Pendidikan Teknologi dan Kejuruan mengemukakan bahwa; 
Komunikasi adalah suatu proses pesan-pesan disampaikan oleh penyampai pesan kepada penerima pesan. Pesan itu dapat berupa perasaan atau hasil pemikiran sendiri atau hanya penerus dari perasaan atau hasil pemikiran orang lain dengan maksud untuk mengubah pengetahuan, keterampilan, dan atau sikap pihak penerima pesan (Suharsimi Arikunto, 1988: 207).

Pengertian komunikasi jika dilihat dari cakupan maknanya demikian luas dan mencakup semua aspek, karena hal tersebut meliputi semua kegiatan yang dilakukan serta dapat memunculkan pesan atau informasi. Sebagaimana yang dikemukakan oleh Onong Uchjana dalam bukunya yang berjudul Dinamika Komunikasi, bahwa;

Komunikasi adalah proses penyampaian informasi atau pesan dari seseorang kepada orang lain untuk memberi tahu atau untuk merubah sikap, pendapat atau perilaku, baik langsung secara lisan maupun tidak langsung melalui media (Onong Uchyana Effendi, 1986: 6).

Melakukan komunikasi tidak hanya penting karena keharusan penyampaian pesan, tetapi komunikasi sangat penting untuk menjadi sarana dalam mengubah sikap, pendapat atau tingkah laku. Dengan komunikasi yang baik, akan dapat dilakukan perubahan-perubahan yang diinginkan.

Berbagai pengertian yang telah dikemukakan di atas, maka dapat dipahami bahwa dalam komunikasi terdapat beberapa unsur yang aktif, sehingga komunikasi tersebut dapat berlangsung. Di antara hal tersebut adalah sebagai berikut;

a. Ada penyampai pesan yang disebut dengan komunikator.

b. Ada isi pesan-pesan yang disampaikan oleh komunikator, kepada penerima pesan.

c. Ada yang menerima pesan-pesan komunikator (komunikan).

d. Ada sarana atau media yang dipakai untuk menyampaikan pesan-pesan komunikator.

Komunikasi yang baik, tentu akan berhasil jika dilakukan dengan cara yang baik pula. Untuk mencapai hal tersebut, maka paling minimal keempat hal tersebut di atas harus ada.

\section{B. Beberapa Bentuk Komunikasi dalam Kehidupan}

Pada bagian ini penulis akan menguraikan beberapa bentuk komunikasi yang banyak dijumpai dalam lapangan kehidupan manusia. Telah sama dipahami bahwa komunikasi dalam kehidupan manusia sangat urgen. Tanpa komunikasi mustahil manusia mampu berbuat dan berinteraksi dengan sesamanya dalam pergaulan hidup.

Terjadinya pertukaran informasi dan pengalaman tindakan lain karena adanya komunikasi antara satu dengan lainnya, sehingga pertukaran informasi itu memberikan hasil yang dapat dipergunakan loleh manusia.

Untuk mendapatkan kejelasan tentang bagaimana komunikasi itudilakukan oleh manusia, maka dikemukakan beberapa bentuk komunikasi seperti yang dijelaskan oleh Onong Uchjana Efendi dalam bukunya yang berjudul Ilmu Komunikasi Teori dan Praktek, sebagai berikut;

1. Komunikasi personal

2. Komunikasi kelompok

3. Komunikasi massa 
4. Komunikasi media (Onong Uchjana Effendi, 1990: 7).

Jika dicermati pembagian tersebut di atas, dapat disimpulkan bahwa komunikasi itu dapat dibedakan atas komunikasi langsung dan komunikasi tidak langsung. Keempat fungsi-fungsi tersebut, sudah mencakup fungsi dari keseluruhan bentuk-bentuk dan jenis komunikasi. Namun, hendaknya perlu diperhatikan bahwa fungsi-fungsi pendidikan dari komunikasi dapat lebih ditonjolkan dari semua fungsi komunikasi yang ada sehingga komunikasi tersebut selalu mengandung nilai-nilai edukatif dan dapat memberi manfaat yang lebih bermakna dan luas.

Selain itu, peranan media komunikasi tidak langsung seperti televisi, radio dan bacaan-bacaan, hendaknya dapat terkontrol dan mendapat pengawasan yang efektif. Hal ini dimaksudkan agar ada semacam seleksi informasi yang masuk kepada masyarakat luas sebagai komunikan.

Karena itu, komunikasi hendaknya dapat dilakukan dengan menetapkan prinsip efektivitas, sehingga komunikasi itu dapat berlangsung dengan tidak menyita banyak waktu. Namun, beberapa bentuk komunikasi dapat saja terjadi secara spontan. Misalnya komunikasi antara anak dengan orang tua dan sebagainya.

\section{Fungsi dan Tujuan Komunikasi}

Dalam kehidupan modern dewasa ini, manusia telah memasuki suatu era yang disebut dengan era informasi, maka komunikasi telah memegang peranan yang sangat penting dalam percaturan kehidupan. Baik dalam skala internasional, regional, nasional, lebih-lebih lagi dalam skala yang lebih kecil seperti lingkungan keluarga.

Karena itu fungsi dan peranan komunikasi senantiasa mengalami dinamisasi serta perubahanperubahan disetiap saat. Hal ini dimungkinkan karena era globalisasi yang berlangsung dengan sangat cepat dan pesat. Jika dilihat secara riil, komunikasi pada dasarnya memiliki beberapa fungsi, yaitu selain fungsi utamanya menyampaikan informasi komunikasi juga mempunyai beberapa fungsi sosial.

Menurut Onong Uchjana Efendi dalam bukunya Dinamika Komunikasi mengemukakan beberapa fungsi tersebut, yaitu;

1. Menyampaikan informasi

2. Sebagai sarana pendidikan

3. Sebagai sarana penghibur

4. Sebagai sarana untuk mempengaruhi (Onong Uchjana Effendi, 1990: 8).

Jika dilihat tujuan komunikasi sebagaimana yang telah disebutkan, dapat disimpulkan bahwa komunikasi pada dasarnya bertujuan agar terjadi perubahan-perubahan, baik dalam hal sikap, perilaku, pendapat atau dalam skala yang lebih luas adalah terjadinya perubahan sosial. 


\section{PENUTUP}

\section{Kesimpulan}

Dari uraian yang telah dideskripsikan terdahulu, maka penulis dapat menarik kesimpulan sebagai berikut:

1. Komunikasi adalah proses aktivitas penyampaian pesan oleh seseorang kepada orang lain, untuk memberi atau mengubah sikap, pendapat atau perilaku, baik secara langsung maupun tidak langsung.

2. Komunikasi antara orang tua dengan anak adalah proses penyampaian pesan, sebagai suatu konsekuensi untuk membentuk diri anak, dalam setiap tahap pertumbuhan dan perkembangannya. Dalam komunikasi ini, orang tua menyiapkan dan memberikan pesan-pesan (sebagai komunikator) dan anak sebagai penerima pesan (komunikan). Pesan yang disampaikan dalam komunikasi dapat dilakukan dalam bentuk tatap muka (komunikasi langsung) maupun dalam bentuk komunikasi tidak langsung melalui sarana atau media.

3. Komunikasi efektif antara orang tua dengan anak adalah proses komunikasi yang dilakukan dengan sengaja dan berencana oleh orang tua di dalam lingkungan keluarga. Dalam proses ini, komunikasi di lingkungan keluarga akan lebih efektif, jika dilaksanakan melalui perencanaan terlebih dahulu.

4. Lingkungan keluarga sebagai lingkungan yang pertama dan utama dalam pendidikan anak, akan menjadi sarana yang sangat besar pengaruhnya dalam penyampaian pesan-pesan komunikasi dari orang tua kepada anak-anaknya.

5. Agar isi pesan komunikasi dapat diterima dengan baik, maka para orang tua dituntut untuk memiliki keterampilan di dalam menyampaikan pesan-pesan komunikasi yang dimaksud. Dalam hal ini tingkat pendidikan orang tua sangat mendukung usaha-usaha kelancaran dan efektivitas komunikasi yang dilaksanakan.

6. Dalam membentuk watak dan sikap hidup anak, maka orang tua harus membina hubungan yang harmonis melalui komunikasi yang terjalin secara baik dan harmonis, sehingga anak akan mudah memahami pesan-pesan dari orang tuanya.

7. Pola interaksi komunikasi yang sebaiknya dibangun antara orang tua dengan anak dilakukan dengan menyesuaikan pola perkembangan kehidupan psikis anak, sehingga mudah terserap dan sejalan dengan pertumbuhan dan perkembangannya.

8. Para orang tua di dalam membangun komunikasi dengan anak hendaknya berpedoman pada prinsip-prinsip pembinaan pendidikan Islam, sehingga nuansa-nuansa komunikasi terjalin secara Islami. 


\section{DAFTAR PUSTAKA}

Al-Qur'an al-Karim.

Al-Maraghi, Ahmad Mustafa. Tafsir al-Maraghi. Juz 9. Cet. I; Semarang: Toha Putra, 1987.

Amini, Ibrahim. Bimbingan Islam untuk Kehidupan Suami Isteri. Cet. XVII; Bandung: Al-Bayan, 2002.

Arifin, Anwar. Strategi Komunikasi. Bandung: Armico, 1984.

Arikunto, Suharsimi. Organisasi dan Administrasi Pendidikan Teknologi dan Kejuruan. Jakarta: Rajawali Press, 1988.

Al-Bilali, Syaikh Abdul Hamid Jasin. Seri Mendidik Anak. Cet. I; Jakarta: Al-I’tishon, 2000.

Daradjat, Zakiah. Ilmu Jiwa Agama. Jakarta: Bulan Bintang, 1990.

Departemen Agama RI. Al-Qur'an dan Terjemahnya. Cet. I; emarang: CV. Toha Putra, 1998.

Departemen Pendidikan dan Kebudayaan RI. Kamus Besar Bahasa Indonesia. Jakarta: Balai Pustaka, 1989.

E. Pino. Kamus Inggris Indonesia. Jakarta: Pradja Paramita, t,th.

Efendi, Onong Uchjana. Dinamika Komunikasi. Bandung: Remaja, Karya, 1986.

Gunarsa, Singgi D. Gunarsa. Psikologi Perkembangan Anak dan Remaja. Jakarta: BPK. Gunung Mulia, 1986.

Hadi, Sutrisno. Metodologi Research. Jilid I. Yogyakarta: Yayasan Penerbit Fakultas Psikologi UGM, 1980.

Harahap, Syahrir. Islam Konsep dan mplementasi Pemberdayaan. Cet. I; Yogyakarta: Wacana Yogya, 1999.

Imam Jalaluddin Abdurrahman bin Abi Bakar as-Suyuthy. Al-jamiush Shagir, Juz I. (t.d.).

Indrakusuma, Amir Daien. Pengantar Ilmu Pendidikan. Surabaya: Usaha Nasional, 1973.

Kartono, Kartini. Psikologi Anak. Bandung: CV. Mandar Maju, 1990.

Langgulung, Hasan. Manusia dan Pendidikan. Jakarta: Pustaka al-Husna, 1986.

Manusia dan Pendidikan (Suatu Analisis Psikologi dan Pendidikan). Jakarta: Pustaka al-Husna, 1986.

Marimba, Ahmad D. Pengantar Filsafat Pendidikan Islam. Bandung: Al-Ma'arif, 1967.

Raliby, Osman. Kamus Internasional Inggris-Indonesia. Jakarta: Bulan Bintang, 1984. 
Robins, James G. dan Barbara S. Jones. Effective for Today's manager, diterjemahkan oleh Drs. R. Thurman Sirait dengan judul "Komunikasi Yang Efektiv Untuk Pejabat dan Usahawan". Jakarta: CV. Edoman Ilmu Jaya, 1986.

Sujanto, Agus. Psikologi Perkembangan. Cet. V; Jakarta: Aksara Baru, 1986.

Surachmad, Winarno. Berkomunikasi dalam Nilai Hidup. Bandung: Tarsito, 1987.

Tanlain, Wens, dkk. Dasar-dasar Ilmu Pendidikan. Cet. I; Jakarta: PT. Gramedia Pustaka Utama, 1989.

Uchjana, Onong Efendi. Komunikasi Teori dan Praktek. Bandung: PT. Remaja Rosdakarya, 1990. 